\title{
THE SHAPE AND SIZE FOR DESIGNING THE UNISEX CLOTHING: A STUDY
}

\author{
SUNITHA VASAN ${ }^{1}$, S. R. PUJAR ${ }^{2}$ \& S. GOPALAKRISHNAN ${ }^{3}$ \\ ${ }^{1}$ Associate Professor, National Institute of Fashion Technology, Chennai, Tamil Nadu, India \\ ${ }^{2}$ Former Director, Sardar Vallabhbhai Patel International School of Textiles \& Management, Coimbatore, Tamil Nadu, India \\ ${ }^{3}$ Head Resource Centre, National Institute of Fashion Technology, Chennai, Tamil Nadu, India
}

\section{ABSTRACT}

Clothing, creates interactions with others, can transmit a vast array of meanings such as identity, value, mood, and attitude. The core value is unisex clothing and transformable, made to fit on different body parts in different ways. The study was carried out with the objective to identify the different body shapes to be considered for unisex clothing, to identify the different sizes of Unisex clothing, to identify the colour and shade preferred for unisex clothing and to frame a shape, size and colour for different body shape towards manufacturing unisex clothing. National Institute of Fashion Technology (NIFT) has 16 Centres throughout India out of which the 4 Centres situated in Bengaluru, Chennai, Hyderabad and Kannur were taken up for the study. Out of 1067 questionnaires distributed 915 had responded and the response rate works out to $85.75 \%$.

Six different body shapes such as Triangle shape, Inverted triangle shape, Rectangle shape, Hourglass shape, Diamond shape and Rounded shapes were considered for the study. The size measurements that are normally taken are for bottom size i.e. waist measurement and top size i.e. chest measurement. For unisex clothing, the bottom has been indicated as less than 28”, 28”, 30", 32" and 34". The top size has been indicated as XXS, XS, S, M, L, XL and XXL. The study also identifies the colour preferences for unisex clothing.

The neutral shades are the most preferred shades by Less than 28 and 28 in XS preferred by Triangle, Rectangle, Diamond and Rounded shapes. The neutral shades are the most preferred shades $28,30,32$ and 34 of $M$ preferred by Inverted Triangle, Rectangle, Hourglass and Rounded shapes whereas the Light shade preferred by Diamond shape. The neutral shade of 32 only preferred by L in Triangle and Inverted triangle shapes, whereas Light shade is preferred by L in Rectangle and Dark shade in Hourglass and Rounded shapes. The dark shades are the most preferred shades by Less than 28 and 28 in XS preferred by Inverted triangle and Hourglass shapes. Earlier studies were carried out among the apparel and fashion designers on their Perception and Awareness on Unisex Clothing. Further, based on the designer's opinion, this study facilitates to identify the body shape and size for unisex clothing.

KEYWORDS: Unisex Clothing, Shape and Size, Colour Preference \& Shades for Unisex Clothing

Received: Dec 11, 2018; Accepted: Dec 31, 2018; Published: Jan 23, 2019; Paper Id.: IJHRMRFEB201913

\section{INTRODUCTION}

Clothing is a basic need in everyday human life. It creates interactions with others and transmits a vast array of meanings such as identity, value, mood, and attitude. These factors paved way for fashion to exhibit the designing.

The concept of Unisex clothing is not a new phenomenon. The society used to adopt the same for infant children and younger children irrespective of the gender. In such situation the size, shape and style does not matter. 
There may not be much difference in the shape and size. In grown up age, the gender has an influence on clothing and fashion.

The core value of unisex clothing is transformable, made to fit on different body parts in different ways. Tilly and William (2015) stated that "there are different ways to accentuate the curves of a woman, or the shape of a man, and we are trying to discover that middle ground". The Gender-neutral clothing is an expanding market and affordability were the key for the apparel market. With most items "it's more about how our costumer styles it than about any amount of masculinity or femininity inherent in the piece" (Ryan, 2015). It was noticed that men were buying at the women's department and vice versa. Today, generations were willing to choose and style for themselves. Here is to argue if the categorizing clothing in gendered sections seems to be out dated. Earlier studies were carried out among the apparel/fashion designers on their Perception and Awareness on Unisex Clothing (Sunitha et al, 2007). Further, based on the designer's opinion, this study facilitates to identify the body shape and size for unisex clothing.

\section{Body Image/Body Shape}

Even though men and women have different bodies, not all men have the same body and nor do all women. In general, the body shape for both men and women falls among the following six different shapes.

- Triangle shape will have a smaller measurement of shoulder and wider measurement on hip

- Inverted triangle/ V-shape will have a broader measurement on the shoulders with a smaller measurement of waist and hip

- Ruler/Rectangle shape will have similar measurements on shoulder, waist \& hip

- Hourglass Shape will have wider measurements of shoulder \& hip with a smaller waist measurement

- Diamond shape will have a smaller measurement of shoulder and hip with wider measurement of the waist

- Rounded shape will have a wider measurement on shoulder, waist and hip

The different body shapes are shown diagrammatically in figure 1 .

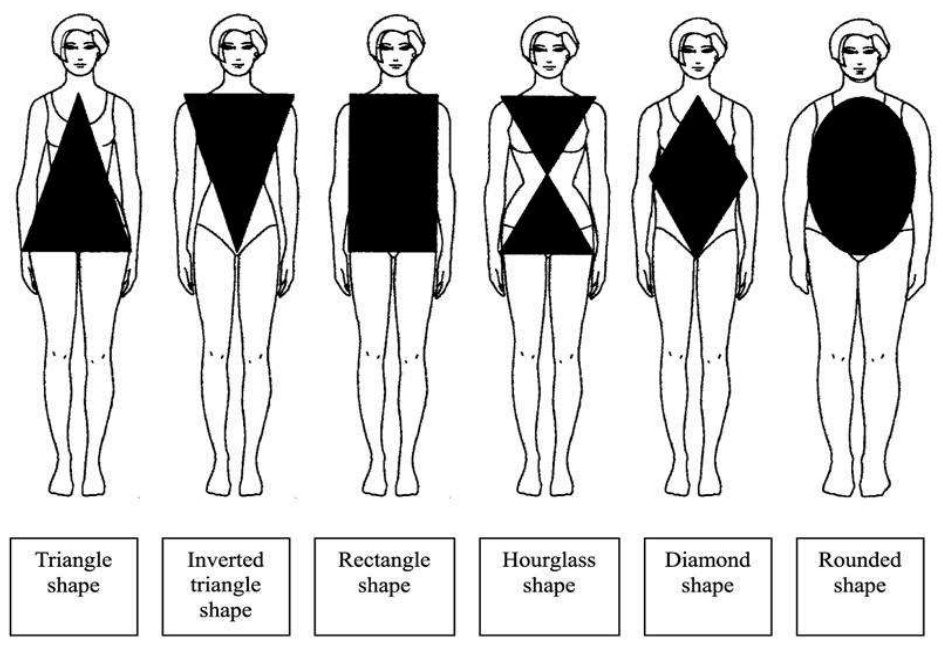

Figure 1: Different Body Shapes 
Unisex sizing is referred to as the same cut of a style is offered in a broader size scale such as xxs-xxl and can be worn by both men and women. Women will typically buy into the smaller range such as xxs-m, whereas men will buy sxxl. The unisex size chart thus derived from men and female size chart has been shown Table 1 below:

Table 1: Unisex Size Chart

\begin{tabular}{|l|c|c|c|c|c|c|c|}
\hline & XXS & XS & S & M & L & XL & XXL \\
\hline Chest & $32-34$ & $34-36$ & $36-38$ & $39-41$ & $42-44$ & $45-47$ & $48-60$ \\
\hline Waist & $23-25$ & $26-28$ & $29-31$ & $32-34$ & $35-37$ & $38-40$ & $41-43$ \\
\hline Hip & $28-33$ & $31-36$ & $34-38$ & $37-42$ & $40-45$ & $43-48$ & $46-51$ \\
\hline
\end{tabular}

The size chart in Table 1 indicates Chest, Waist and Hip for various sizes such as XXS, XS, S, M,L, XL and XML for Unisex clothing.

\section{REVIEW OF LITERATURE}

Lorber (1994) notes how gender roles change in society. She refers to fathers taking on the role of a nurturing father, girls and boys wearing unisex clothing and men and women getting the same education and working the same jobs. Wearing the right clothes, the appropriate dress for the occasion, fitting in rather than standing out, are the dominant concerns of most people. As Simmel pointed out, fashion must be understood in terms of the competing desires for social equalization and for individual differentiation, the interplay between the wish to fit in and to stand out, (Simmel 1904/1971). Clarke and Miller (2002) argue that postmodern fluidity and optionality, produce anxiety as much as pleasure and agency, with the wish to choose the right clothes. Gender has to break down into three distinct pieces; your gender identity, gender expression and biological sex. Gender identity is who know oneself to be, gender expression is the way you present yourself through dressing and manners (often to align with social norms), and third there is biological sex, which is based on your sex characteristics. (Killermann, 2014).

Joe Hallock's polls on colour preferences by gender and age yield some interesting results. Those results include Female Top 3 Favourite Colours: Blue, Purple, Green (all cool colours), Female Top 3 Least Favourite Colours: Orange, Brown, Gray (warm and neutral colours); among favourite colours, preferences for green decrease with age (all genders); Among favourite colours, preferences for purple increase with age (all genders).

\section{OBJECTIVES}

\section{The objectives of the study are}

- $\quad$ To identify the different body shapes for unisex clothing

- $\quad$ To identify the different sizes of Unisex clothing

- $\quad$ To identify the colour and shades preferred for unisex clothing

- To identify the size and colour for different body shapes towards manufacturing unisex clothing.

\section{Data Capture}

National Institute of Fashion Technology (NIFT) has 16 Centres throughout India out of which the 4 Centres situated in Bengaluru, Chennai, Hyderabad and Kannur were taken up for the study. A structured questionnaire was distributed among 1067 persons of NIFT faculty and students. Out of 1067 questionnaires distributed 915 had responded 
and the response rate works out to $85.75 \%$.

\section{Demographic Data}

The demographic details, including city, gender and Category were shown in Table 2.

Table 2: Demographic Details

\begin{tabular}{|c|l|c|c|c|}
\hline S. No & \multicolumn{1}{|c|}{ Description } & Frequency & \% & Cumulative \% \\
\hline \multicolumn{5}{|c|}{ Centres } \\
\hline 1 & Bengaluru & 259 & 28.3 & 28.3 \\
\hline 2 & Chennai & 268 & 29.3 & 57.6 \\
\hline 3 & Hyderabad & 211 & 23.1 & 80.7 \\
\hline 4 & Kannur Category of the Respondents \\
\hline \multicolumn{5}{|c|}{ Gender } \\
\hline 1 & PG & 135 & 14.8 & 14.8 \\
\hline 2 & UG & 624 & 68.2 & 83.0 \\
\hline 3 & Faculty members & 156 & 17.0 & 100.0 \\
\hline \multicolumn{5}{|c|}{ Overall } \\
\hline 1 & Male & 278 & 30.4 & 30.4 \\
\hline 2 & Female & 637 & 69.6 & 100.0 \\
\hline \multicolumn{5}{|c|}{ Total } \\
\hline
\end{tabular}

Out of 915 respondents, $624(68.2 \%)$ were UG Students, 135 (14.8\%) were PG Students and $156(17 \%)$ were the Faculty Members from all the southern NIFT Centres. There were 278 (30.4) male respondents and 637 (69.6) female respondents. Among the 915 respondents Bengaluru (259, 28.3); Chennai (268, 29.3); Hyderabad (211, 23.1) and Kannur $(177,19.3)$ responded.

In order to identify whether a geographic domain, gender and age will have an impact on unisex clothing, the respondents have been analysed by gender, geographic domain and age (indirectly calculated with designation) and the same has been shown in Table 3.

Table 3: Centre Vs Gender and Category of Respondents

\begin{tabular}{|c|c|c|c|c|c|c|}
\hline S. No & Centre & Gender & PG & UG & Faculty & Total \\
\hline \multirow{2}{*}{1} & \multirow{2}{*}{ Bengaluru } & Male & $\begin{array}{c}10 \\
(3.6)\end{array}$ & $\begin{array}{c}52 \\
(18.7)\end{array}$ & $\begin{array}{c}19 \\
(6.8)\end{array}$ & $\begin{array}{c}81 \\
(29.1)\end{array}$ \\
\hline & & Female & $\begin{array}{c}29 \\
(4.6)\end{array}$ & $\begin{array}{c}124 \\
(19.5)\end{array}$ & $\begin{array}{c}25 \\
(3.9)\end{array}$ & $\begin{array}{c}178 \\
(27.9)\end{array}$ \\
\hline \multirow{2}{*}{2} & \multirow{2}{*}{ Chennai } & Male & $\begin{array}{c}11 \\
(4.0)\end{array}$ & $\begin{array}{c}56 \\
(20.1) \\
\end{array}$ & $\begin{array}{r}12 \\
(4.3) \\
\end{array}$ & $\begin{array}{c}79 \\
(28.4) \\
\end{array}$ \\
\hline & & Female & $\begin{array}{c}22 \\
(3.5)\end{array}$ & $\begin{array}{c}136 \\
(21.4)\end{array}$ & $\begin{array}{c}31 \\
(4.9)\end{array}$ & $\begin{array}{c}189 \\
(29.7)\end{array}$ \\
\hline \multirow{2}{*}{3} & \multirow{2}{*}{ Hyderabad } & Male & $\begin{array}{c}9 \\
(3.2)\end{array}$ & $\begin{array}{c}44 \\
(15.8)\end{array}$ & $\begin{array}{c}11 \\
(4.0)\end{array}$ & $\begin{array}{c}64 \\
(23.0)\end{array}$ \\
\hline & & Female & $\begin{array}{c}13 \\
(2.0) \\
\end{array}$ & $\begin{array}{c}104 \\
(16.3) \\
\end{array}$ & $\begin{array}{c}30 \\
(4.7)\end{array}$ & $\begin{array}{c}147 \\
(23.1) \\
\end{array}$ \\
\hline \multirow{2}{*}{4} & \multirow{2}{*}{ Kannur } & Male & $\begin{array}{c}12 \\
(4.3) \\
\end{array}$ & $\begin{array}{c}31 \\
(11.2) \\
\end{array}$ & $\begin{array}{c}11 \\
(4.0) \\
\end{array}$ & $\begin{array}{c}54 \\
(19.4) \\
\end{array}$ \\
\hline & & Female & $\begin{array}{c}29 \\
(4.6)\end{array}$ & $\begin{array}{c}77 \\
(12.1) \\
\end{array}$ & $\begin{array}{c}17 \\
(2.7)\end{array}$ & $\begin{array}{c}123 \\
(19.3) \\
\end{array}$ \\
\hline \multirow{2}{*}{\multicolumn{2}{|c|}{ Total }} & Male & $\begin{array}{c}42 \\
(15.1)\end{array}$ & $\begin{array}{c}183 \\
(65.8)\end{array}$ & $\begin{array}{c}53 \\
(19.1)\end{array}$ & $\begin{array}{c}278 \\
(100.0)\end{array}$ \\
\hline & & Female & $\begin{array}{c}93 \\
(14.6)\end{array}$ & $\begin{array}{c}441 \\
(69.2)\end{array}$ & $\begin{array}{c}103 \\
(16.2)\end{array}$ & $\begin{array}{c}637 \\
(100.0)\end{array}$ \\
\hline
\end{tabular}


Values in parenthesis denotes the Percentage

It can be inferred from the table 3 that the questionnaires have been evenly distributed over the geographic domain and age. However the female sample seems to be the higher side since the success of the fashion and clothing primarily depends on the female than the male. Therefore, it can be inferred that the findings can be universalized.

\section{Data Analysis}

The number of respondents on body shape and the size measurement from the top and bottom were analysed and the same is shown in Table 4.

Table 4: Body Shape Vs Size Measurement - Top - Bottom

\begin{tabular}{|c|l|c|c|c|}
\hline S. No & \multicolumn{1}{|c|}{ Description } & Frequency & \% & Cumulative \% \\
\hline \multicolumn{5}{|c|}{ Body Shape } \\
\hline 1 & Triangle Shape & 129 & 14.10 & 14.1 \\
\hline 2 & Inverted triangle Shape & 122 & 13.33 & 27.43 \\
\hline 3 & Rectangle Shape & 396 & 43.28 & 70.71 \\
\hline 4 & Hourglass Shape & 268 & 29.29 & 100.00 \\
\hline \multicolumn{5}{|c|}{ Top Size } \\
\hline 1 & XS & 105 & 11.48 & 14.1 \\
\hline 2 & S & 307 & 33.55 & 45.03 \\
\hline 3 & M & 491 & 53.66 & 98.69 \\
\hline 4 & L & 42 & 1.31 & 100.00 \\
\hline \multicolumn{5}{|c|}{ Lottom Size } \\
\hline 1 & Less than 28 & 431 & 4.59 & 4.59 \\
\hline 2 & 28 & 244 & 26.67 & 78.36 \\
\hline 3 & 30 & 156 & 16.94 & 95.30 \\
\hline 4 & 32 & 43 & 4.7 & 100.00 \\
\hline 5 & 34 & 915 & 100.0 & \\
\hline \multicolumn{5}{|c|}{ OVERALL } \\
\hline \multicolumn{5}{|c|}{ Total } \\
\hline
\end{tabular}

Out of 915 respondents, 396 (43.28\%) were belongs to rectangle shape, followed by an hourglass shape (268, $29.29 \%)$; triangle shape $(129,14.10 \%)$ and inverted triangle shape $(122,13.33 \%)$. None of the respondents fall under the category of diamond and rounded shape.

The majority of the respondents have top size - "M" (491, 53.66\%). It is followed by "S" (307, 33.55\%), "XS" $(105,11.48 \%)$ and "L" $(12,1.31 \%)$. The highest no. of bottom size respondents falls under the category of $28 "(431$, $47.1 \%)$. It is followed by 30" (244, 26.67\%), 32" (156, 16.94\%), 34” (43, 4.7\%) and Less than 28” (42, 4.59\%).

\section{Size Measurement - Top - Bottom}

The size measurement that are considered are for upper and lower garment which are mentioned as top size and bottom size. The bottom has been indicated as Less than 28”, 28”, 30", 32" and 34" and the top size are indicated as XS, S, $\mathrm{M}$ and $\mathrm{L}$ where the measurements are in inches; the same has been shown in Table 5. 
Table 5: Body Size Measurement - Top\& Bottom

\begin{tabular}{|c|c|c|c|c|c|c|}
\hline \multirow{2}{*}{ Description } & \multicolumn{5}{c|}{ Top Size } & \multirow{2}{*}{ Total } \\
\cline { 3 - 7 } & Less than 28 & 42 & - & - & - & 42 \\
\cline { 2 - 7 } & $\mathbf{2 8}$ & 63 & 287 & 81 & - & 431 \\
\cline { 2 - 7 } & $\mathbf{3 0}$ & - & 20 & 224 & - & 244 \\
\cline { 2 - 7 } Bottom \\
\cline { 2 - 7 } Size & $\mathbf{3 2}$ & - & - & 143 & 12 & 156 \\
\cline { 2 - 7 } & $\mathbf{3 4}$ & - & - & 43 & - & 43 \\
\hline \multicolumn{2}{|c|}{ Total } & $\mathbf{1 0 5}$ & $\mathbf{3 0 7}$ & $\mathbf{4 9 1}$ & $\mathbf{1 2}$ & $\mathbf{9 1 5}$ \\
\hline
\end{tabular}

\section{Body Shape Vs Size Measurement - Top - Bottom}

The size matrix table for Bottom and Top indicates that 63 out of 105 XS respondents have the bottom size of 28 ". The remaining 42 fall under the category of Less than 28 ". None of the respondents of XS category fall under the bottom sizes of 30,32 and 34 inches.

The size matrix table for Bottom and Top indicates that 287 out of $307 \mathrm{~S}$ respondents have the bottom size of 28 ". The remaining 20 fall under the category of 30". None of the respondents of S category fall under the bottom sizes of 28 , 32 and 34 inches.

The size matrix table for Bottom and Top indicates that 81 out of $491 \mathrm{M}$ respondents have the bottom size of 28 ". It is followed by 224 in 30", 143 in 32" and 43 in 34" of bottom size. None of the respondents of M category fall under the bottom size of Less than 28 inches.

The size matrix table for Bottom and Top indicates that $12 \mathrm{~L}$ respondents have the bottom size of 32 ". None of the respondents of L category fall under the bottom sizes of Less than 28, 28, and 34 inches.

\section{Body Shape Vs Size Measurement - Top - Bottom}

The body shapes of the respondents fall under the four categories such as Triangle Shape,

Inverted triangle Shape, Rectangle Shape and Hourglass Shape. The body shapes of the respondents were further analysed based on Top and Bottom size which is shown in Table 6.

Table 6: Body Shape Vs Measurement - Top\& Bottom

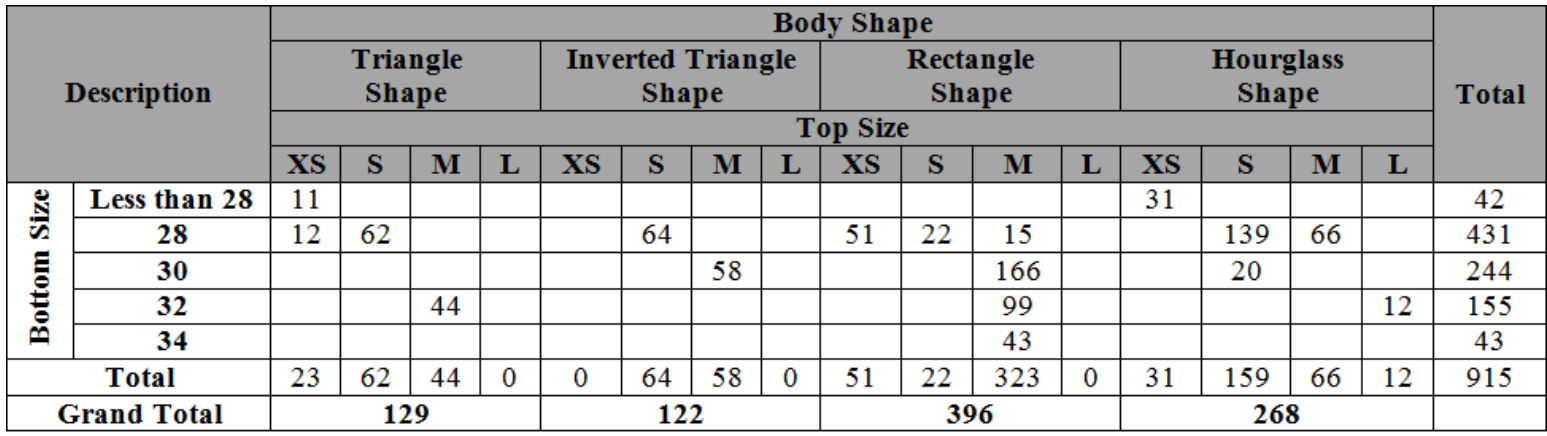

Out of the 129 who were in Triangle shape, 23 belongs to the XS category of which 11 are Less than 28 and 12 were 28 ". Similarly, all the 62 respondents of the size 28 " and 44 of M size belongs to 32 ". None of the respondents of L size falls under any of the bottom size. Out of 122 of Inverted triangle shape, 64 belongs to S category of 28 ” and $58 \mathrm{M}$ category of 30". None of the respondents of XS and L size falls under any of the bottom size. 
Out of 396 of Rectangle shape, 51 of XS and 22 of S belongs to 28”. Out of 323 of M category, 15 belongs to 28 ", 166 belongs to 30", 99 belongs to 32" and 43 belongs to 34. None of the respondents of any sizes falls under Less than 28 " of bottom size. Out of 268 of Hourglass shape, 31 of XS falls under Less than 28”. Out of 159, 139 of S belongs to 28 " and the remaining 20 belongs to 30". All the 66 under M category falls on bottom size 28". Similarly, all the 12 of L size falls in the bottom size of 32 . None of the respondents belong to 34 " of bottom size.

Table 6 enables to infer that the body shape is in relation to the top and bottom sizes and the ones that are predominant are shown in Table 7.

Table 7: Body Shape Vs Size Measurement - Top - Bottom

\begin{tabular}{|c|l|c|}
\hline \multirow{2}{*}{ Triangle Shape } & XS & Less than 28, 28 \\
\cline { 2 - 3 } & $\mathrm{S}$ & 28 \\
\cline { 2 - 3 } Inverted Triangle Shape & $\mathrm{M}$ & 32 \\
\hline \multirow{2}{*}{ Rectangle Shape } & $\mathrm{S}$ & 28 \\
\cline { 2 - 3 } & $\mathrm{M}$ & 30 \\
\hline \multirow{2}{*}{ Hourglass Shape } & $\mathrm{XS}, \mathrm{S}, \mathrm{M}$ & 28 \\
\cline { 2 - 3 } & $\mathrm{M}$ & $30,32,34$ \\
\hline & $\mathrm{XS}$ & 28 \\
\cline { 2 - 3 } & $\mathrm{S}$ & 28,30 \\
\cline { 2 - 3 } & $\mathrm{M}$ & 28 \\
\cline { 2 - 3 } & $\mathrm{L}$ & 32 \\
\hline
\end{tabular}

It can be seen from Table $6 \& 7$ that

- The respondents fall in the body shape of Triangle shape, Inverted triangle shape, Rectangle Shape and Hourglass shape

- $\quad$ Respondents with Triangle Shaped figure preferred Top Size as Small \& Bottom Size as 28 which is followed by M size Top \& 32 size for Bottom.

- Inverted Triangle Shaped figure preferred S size Top \& 28 size Bottom followed by M size Top \& 30 size Bottom

- $\quad$ Rectangle shaped figure preferred M size Top \& 30 size Bottom followed by M size Top \& 32 size Bottom

- Hourglass Shape figure preferred S size Top \& 28 size Bottom followed by M size Top \& 28 size Bottom

\section{Colour Prediction for Different Body Shape}

The colour preferences of male and female generally differ. In the case of Unisex clothing it is essential to identify the most preferred colour. Therefore the colour preferences of different body shape have been studied and the same is shown in Table 8. The respondents were asked to predict the colour for different body shape such as:

- Triangle shape

- Inverted triangle shape

- Rectangle shape

- Hourglass shape

- Diamond shape 
- $\quad$ Rounded shape

\section{Triangle Shape}

The triangle body shape respondents and the colour preferences are shown in Table 8 .

Table 8: Triangle Shape - Shape Vs Size Measurement Top and Bottom and Colour Preference

\begin{tabular}{|c|c|c|c|c|c|c|}
\hline $\begin{array}{c}\text { Bottom } \\
\text { Size }\end{array}$ & $\begin{array}{l}\text { Top } \\
\text { Size }\end{array}$ & $\begin{array}{c}\text { Light } \\
\text { Shades }\end{array}$ & $\begin{array}{c}\text { Dark } \\
\text { Shades }\end{array}$ & Neutral & $\begin{array}{l}\text { Bright } \\
\text { Shades }\end{array}$ & Total \\
\hline $\begin{array}{c}\text { Less } \\
\text { than } 28\end{array}$ & XS & & $\begin{array}{c}11 \\
(26.2)\end{array}$ & $\begin{array}{c}31 \\
(73.8)\end{array}$ & & $\begin{array}{c}42 \\
(100.0)\end{array}$ \\
\hline \multirow{3}{*}{28} & XS & $\begin{array}{c}51 \\
(11.8)\end{array}$ & $\begin{array}{c}12 \\
(2.8)\end{array}$ & & & $\begin{array}{c}63 \\
(14.6)\end{array}$ \\
\hline & $S$ & $\begin{array}{c}12 \\
(2.8)\end{array}$ & $\begin{array}{c}73 \\
(16.9)\end{array}$ & $\begin{array}{c}110 \\
(25.5)\end{array}$ & $\begin{array}{c}92 \\
(21.3) \\
\end{array}$ & $\begin{array}{c}287 \\
(66.6) \\
\end{array}$ \\
\hline & M & & & $\begin{array}{c}66 \\
(15.3)\end{array}$ & $\begin{array}{c}15 \\
(3.5)\end{array}$ & $\begin{array}{c}81 \\
(18.8)\end{array}$ \\
\hline \multirow{2}{*}{30} & $S$ & & & $\begin{array}{c}20 \\
(8.2)\end{array}$ & & $\begin{array}{c}20 \\
(8.2)\end{array}$ \\
\hline & M & $\begin{array}{c}73 \\
(29.9)\end{array}$ & & $\begin{array}{c}11 \\
(4.5)\end{array}$ & $\begin{array}{c}140 \\
(57.4)\end{array}$ & $\begin{array}{c}224 \\
(91.8)\end{array}$ \\
\hline \multirow{2}{*}{32} & M & & $\begin{array}{c}12 \\
(7.7) \\
\end{array}$ & $\begin{array}{c}131 \\
(84.5)\end{array}$ & & $\begin{array}{c}143 \\
(92.3) \\
\end{array}$ \\
\hline & $\mathrm{L}$ & & & $\begin{array}{c}12 \\
(7.7)\end{array}$ & & $\begin{array}{c}12 \\
(7.7)\end{array}$ \\
\hline 34 & M & & $\begin{array}{c}43 \\
(100.0)\end{array}$ & & & $\begin{array}{c}43 \\
(100.0)\end{array}$ \\
\hline \multicolumn{2}{|c|}{ Total } & 136 & 151 & 381 & 247 & 915 \\
\hline
\end{tabular}

Values in parenthesis denotes the Percentage

In the case of triangle shape, 136 prefer light shade, 151 prefer dark shade, 381 prefer neutral shades and 247 prefer bright shades. Among 136 of light shades, 51 of XS and 12 of S size Top and has 28" bottoms. The remaining 73 have bottom of 30" and top of M size. Out of 151 of dark shades, 11 have top of XS bottom Less than 28 " and 12 have top of 28 "; 73 of size $\mathrm{S}$ with a bottom of 28 ", 12 have top of $\mathrm{M}$ with a bottom of 32 " and 43 have top of M with a bottom of $34 "$.

Out of 381 of neutral shades, 31 have XS Top with bottom of Less than 28"; 110 of S, size Top with a bottom of 28 " and 20 with a bottom of 30". 66 have top size M with a bottom of 28"; 11 of Top Size M with a bottom of 30" and 131 of Top size M with bottom size of 32". Out of 247 of bright shades, 92 have top size S with bottom size 28 ". 15 have top size M with a bottom of 28 " and 140 have top size M with a bottom of 30 ".

\section{Inverted Triangle Shape}

The Inverted triangle body shape respondents colour preferences are shown in Table 9. 
Table 9: Inverted Triangle Shape Vs Size Measurement -

Top and Bottom and Colour Preference

\begin{tabular}{|c|c|c|c|c|c|c|}
\hline $\begin{array}{c}\text { Bottom } \\
\text { Size }\end{array}$ & $\begin{array}{l}\text { Top } \\
\text { Size } \\
\end{array}$ & $\begin{array}{c}\text { Light } \\
\text { Shades } \\
\end{array}$ & $\begin{array}{c}\text { Dark } \\
\text { Shades } \\
\end{array}$ & Neutral & $\begin{array}{l}\text { Bright } \\
\text { Shades }\end{array}$ & Total \\
\hline $\begin{array}{c}\text { Less } \\
\text { than } 28\end{array}$ & XS & & $\begin{array}{c}20 \\
(47.6)\end{array}$ & $\begin{array}{c}11 \\
(26.2)\end{array}$ & $\begin{array}{c}11 \\
(26.2)\end{array}$ & $\begin{array}{c}42 \\
(100.0) \\
\end{array}$ \\
\hline \multirow{3}{*}{28} & XS & $\begin{array}{c}12 \\
(2.8)\end{array}$ & $\begin{array}{c}51 \\
(11.8)\end{array}$ & & & $\begin{array}{c}63 \\
(14.6)\end{array}$ \\
\hline & $S$ & $\begin{array}{c}87 \\
(20.2) \\
\end{array}$ & $\begin{array}{c}47 \\
(10.9) \\
\end{array}$ & $\begin{array}{c}22 \\
(5.1) \\
\end{array}$ & $\begin{array}{c}131 \\
(30.4) \\
\end{array}$ & $\begin{array}{c}287 \\
(66.6) \\
\end{array}$ \\
\hline & M & $\begin{array}{c}15 \\
(3.5)\end{array}$ & $\begin{array}{c}66 \\
(15.3)\end{array}$ & & & $\begin{array}{c}81 \\
(18.8)\end{array}$ \\
\hline \multirow{2}{*}{30} & S & & $\begin{array}{c}20 \\
(8.2)\end{array}$ & & & $\begin{array}{c}20 \\
(8.2) \\
\end{array}$ \\
\hline & M & $\begin{array}{c}74 \\
(30.3) \\
\end{array}$ & $\begin{array}{c}69 \\
(28.3) \\
\end{array}$ & $\begin{array}{c}81 \\
(33.2) \\
\end{array}$ & & $\begin{array}{c}224 \\
(91.8)\end{array}$ \\
\hline \multirow{2}{*}{32} & M & & $\begin{array}{c}143 \\
(92.3)\end{array}$ & & & $\begin{array}{c}143 \\
(92.3)\end{array}$ \\
\hline & $\mathrm{L}$ & & & $\begin{array}{c}12 \\
(7.7)\end{array}$ & & $\begin{array}{c}12 \\
(7.7)\end{array}$ \\
\hline 34 & M & & & $\begin{array}{c}43 \\
(100.0)\end{array}$ & & $\begin{array}{c}43 \\
(100.0)\end{array}$ \\
\hline \multicolumn{2}{|c|}{ Total } & 188 & 416 & 169 & 142 & \\
\hline
\end{tabular}

Values in parenthesis denotes the Percentage

In the case of Inverted triangle shape, 188 prefer light shade, 416 prefer dark shade, 169 prefer neutral shades and 142 prefer bright shades. Among 188 of light shades, 12 of XS, 87 of S and 15 of M sizes belongs to 28". The remaining 74 belongs to 30" of M size top. Out of 416 of dark shades, 20 of XS belong to less than 28" bottom. 51 of XS, 47 of S and 66 belong to 28 " bottom. 20 of size S and 69 of M belongs to 30" bottom. The remaining 143 of M size belongs to 32 " bottom.

Out of 169 of neutral shades, 11 XS belongs to Less than 28”; 22 of S belongs to 28”, 81 belongs to 30 ”, 12 belongs to L of 32 " and $43 \mathrm{M}$ belongs to 34 . Out of 142 of bright shades, 11 belongs to XS of size Less than 28 ", 131 belongs to $\mathrm{S}$ of 28 ".

\section{Rectangle Shape}

The Rectangle body shape respondents' colour preferences are shown in Table 10.

Table 10: Rectangle Shape Vs Size Measurement Top and Bottom and Colour Preference

\begin{tabular}{|c|c|c|c|c|c|c|}
\hline $\begin{array}{c}\text { Bottom } \\
\text { Size } \\
\end{array}$ & $\begin{array}{l}\text { Top } \\
\text { Size } \\
\end{array}$ & $\begin{array}{c}\text { Light } \\
\text { Shades }\end{array}$ & $\begin{array}{c}\text { Dark } \\
\text { Shades } \\
\end{array}$ & Neutral & $\begin{array}{l}\text { Bright } \\
\text { Shades } \\
\end{array}$ & Total \\
\hline $\begin{array}{c}\text { Less } \\
\text { than } 28\end{array}$ & XS & $\begin{array}{c}11 \\
(26.2)\end{array}$ & $\begin{array}{c}11 \\
(26.2)\end{array}$ & $\begin{array}{c}20 \\
(47.6)\end{array}$ & & $\begin{array}{c}42 \\
(100.0)\end{array}$ \\
\hline \multirow{3}{*}{28} & XS & & $\begin{array}{c}12 \\
(2.8)\end{array}$ & $\begin{array}{c}51 \\
(11.8)\end{array}$ & & $\begin{array}{c}63 \\
(14.6)\end{array}$ \\
\hline & $S$ & $\begin{array}{c}33 \\
(7.7)\end{array}$ & $\begin{array}{c}196 \\
(45.5)\end{array}$ & $\begin{array}{c}58 \\
(13.5)\end{array}$ & & $\begin{array}{c}287 \\
(66.6)\end{array}$ \\
\hline & M & $\begin{array}{c}66 \\
(15.3)\end{array}$ & & $\begin{array}{c}15 \\
(3.5)\end{array}$ & & $\begin{array}{c}81 \\
(18.8)\end{array}$ \\
\hline \multirow[t]{2}{*}{30} & $S$ & & & $\begin{array}{c}20 \\
(8.2)\end{array}$ & & $\begin{array}{c}20 \\
(8.2) \\
\end{array}$ \\
\hline & $\mathrm{M}$ & 11 & 155 & 58 & & 224 \\
\hline
\end{tabular}




\begin{tabular}{|c|l|c|c|c|c|c|}
\hline & & $(4.5)$ & $(63.5)$ & $(23.8)$ & & $(91.8)$ \\
\hline \multirow{3}{*}{32} & $\mathrm{M}$ & & & $\begin{array}{c}143 \\
(92.3)\end{array}$ & & $\begin{array}{c}143 \\
(92.3)\end{array}$ \\
\cline { 2 - 7 } & $\mathrm{L}$ & $\begin{array}{c}12 \\
(7.7)\end{array}$ & & & & $\begin{array}{c}12 \\
(7.7)\end{array}$ \\
\hline \multirow{2}{*}{34} & $\mathrm{M}$ & $\begin{array}{c}43 \\
(100.0)\end{array}$ & & & & $\begin{array}{c}43 \\
(100.0)\end{array}$ \\
\hline \multicolumn{2}{|c|}{ Total } & $\mathbf{1 7 6}$ & $\mathbf{3 7 4}$ & $\mathbf{3 6 5}$ & & \\
\hline
\end{tabular}

Values in parenthesis denotes the Percentage

In the case of Rectangle shape, 176 prefer light shade, 374 prefer dark shade and 365 prefer neutral shades. The respondents of Rectangle shape have not preferred bright shades at all. Among 176 of light shades, 11 of XS belongs to Less than 28. 33 of S and 66 of M belongs to 28”. 11 of M size belongs to 30”. The remaining 12 belongs to 32 ” of L size and 43 belongs to M of 34". Out of 374 of dark shades, 20 of XS belong to less than 28". 12 of XS and196 of S belong to 28 ". The remaining 155 belongs to $\mathrm{M}$ size of 30 ”.

Out of 365 of neutral shades, 20 XS belongs to Less than 28"; 51 of XS, 58 of S and 15 of M belongs to 28 ”. 20 of S and 58 of M belongs to 30”. 143 belongs to M size of 32”.

\section{Hour Glass Shape}

The Hour glass body shape respondents colour preferences were shown in Table 11.

Table 11: Hourglass Shape Vs Size Measurement Top and Bottom and Colour Preference

\begin{tabular}{|c|c|c|c|c|c|c|}
\hline $\begin{array}{l}\text { Bottom } \\
\text { Size }\end{array}$ & $\begin{array}{l}\text { Top } \\
\text { Size }\end{array}$ & $\begin{array}{c}\text { Light } \\
\text { Shades }\end{array}$ & $\begin{array}{c}\text { Dark } \\
\text { Shades }\end{array}$ & Neutral & $\begin{array}{l}\text { Bright } \\
\text { Shades }\end{array}$ & Total \\
\hline $\begin{array}{c}\text { Less } \\
\text { than } 28\end{array}$ & XS & $\begin{array}{c}11 \\
(26.2)\end{array}$ & $\begin{array}{c}20 \\
(47.6)\end{array}$ & & $\begin{array}{c}11 \\
(26.2)\end{array}$ & $\begin{array}{c}42 \\
(100.0)\end{array}$ \\
\hline \multirow{3}{*}{28} & XS & & & $\begin{array}{c}12 \\
(2.8)\end{array}$ & $\begin{array}{c}51 \\
(11.8)\end{array}$ & $\begin{array}{c}63 \\
(14.6) \\
\end{array}$ \\
\hline & S & & $\begin{array}{c}142 \\
(32.9) \\
\end{array}$ & $\begin{array}{c}133 \\
(30.9) \\
\end{array}$ & $\begin{array}{c}12 \\
(2.8) \\
\end{array}$ & $\begin{array}{c}287 \\
(66.6) \\
\end{array}$ \\
\hline & M & & $\begin{array}{c}15 \\
(3.5)\end{array}$ & $\begin{array}{c}66 \\
(15.3)\end{array}$ & & $\begin{array}{c}81 \\
(18.8)\end{array}$ \\
\hline \multirow{2}{*}{30} & S & & $\begin{array}{c}20 \\
(8.2)\end{array}$ & & & $\begin{array}{c}20 \\
(8.2)\end{array}$ \\
\hline & M & & $\begin{array}{c}66 \\
(27.0) \\
\end{array}$ & $\begin{array}{c}84 \\
(34.4) \\
\end{array}$ & $\begin{array}{c}74 \\
(30.3) \\
\end{array}$ & $\begin{array}{c}224 \\
(91.8) \\
\end{array}$ \\
\hline \multirow{2}{*}{32} & M & & $\begin{array}{c}99 \\
(63.9)\end{array}$ & & $\begin{array}{c}44 \\
(28.4)\end{array}$ & $\begin{array}{c}143 \\
(92.3)\end{array}$ \\
\hline & $\mathrm{L}$ & & $\begin{array}{c}12 \\
(7.7)\end{array}$ & & & $\begin{array}{c}12 \\
(7.7)\end{array}$ \\
\hline 34 & M & & $\begin{array}{c}43 \\
(100.0)\end{array}$ & & & $\begin{array}{c}43 \\
(100.0)\end{array}$ \\
\hline \multicolumn{2}{|c|}{ Total } & 11 & 417 & 295 & 192 & \\
\hline
\end{tabular}

Values in parenthesis denotes the Percentage

In the case of Hourglass shape, 11 prefer light shade, 417 prefer dark shade, 295 prefer neutral shades and 192 prefer bright shades. All the 11 of light shades belongs to XS of less than 28". Out of 417 of dark shades, 20 of XS belong to Less than 28". 142 of XS and 15 of S belong to 28 ". 20 of size S and 66 of M belongs to 30 ". 99 of M and 12 of L belongs to 32". The remaining 43 of M belongs to 34". 
Out of 295 of neutral shades, 12of XS, 133 of S and 66 of M belongs 28”. The remaining 84 of belongs to 30”. Out of 192 of bright shades, 11 belongsto XS of size less than 28”, 51 of XS and 12 of S belongs to 28 ".74 of M belongs to 30 " and 44 of M belongs to 32 .

\section{DIAMOND SHAPE}

The diamond body shape respondents colour preferences were shown in Table 12.

Table 12: Diamond Shape Vs Size Measurement Top and Bottom and Colour Preference

\begin{tabular}{|c|c|c|c|c|c|c|}
\hline $\begin{array}{l}\text { Bottom } \\
\text { Size }\end{array}$ & $\begin{array}{l}\text { Top } \\
\text { Size }\end{array}$ & $\begin{array}{c}\text { Light } \\
\text { Shades }\end{array}$ & $\begin{array}{c}\text { Dark } \\
\text { Shades }\end{array}$ & Neutral & $\begin{array}{l}\text { Bright } \\
\text { Shades }\end{array}$ & Total \\
\hline $\begin{array}{c}\text { Less } \\
\text { than } 28\end{array}$ & XS & & $\begin{array}{c}11 \\
(26.2)\end{array}$ & $\begin{array}{c}31 \\
(73.8)\end{array}$ & & $\begin{array}{c}42 \\
(100.0)\end{array}$ \\
\hline \multirow{3}{*}{28} & XS & & $\begin{array}{c}51 \\
(11.8) \\
\end{array}$ & & $\begin{array}{c}12 \\
(2.8) \\
\end{array}$ & $\begin{array}{c}63 \\
(14.6) \\
\end{array}$ \\
\hline & $S$ & $\begin{array}{c}74 \\
(17.2) \\
\end{array}$ & $\begin{array}{c}60 \\
(13.9) \\
\end{array}$ & $\begin{array}{c}124 \\
(28.8) \\
\end{array}$ & $\begin{array}{c}29 \\
(6.7) \\
\end{array}$ & $\begin{array}{c}287 \\
(66.6) \\
\end{array}$ \\
\hline & M & $\begin{array}{c}15 \\
(3.5) \\
\end{array}$ & & & $\begin{array}{c}66 \\
(15.3) \\
\end{array}$ & $\begin{array}{c}81 \\
(18.8) \\
\end{array}$ \\
\hline \multirow{2}{*}{30} & $S$ & & & $\begin{array}{c}20 \\
(8.2)\end{array}$ & & $\begin{array}{c}20 \\
(8.2)\end{array}$ \\
\hline & M & $\begin{array}{c}139 \\
(57.0) \\
\end{array}$ & $\begin{array}{c}11 \\
(4.5) \\
\end{array}$ & $\begin{array}{c}74 \\
(30.3) \\
\end{array}$ & & $\begin{array}{c}224 \\
(91.8) \\
\end{array}$ \\
\hline \multirow{2}{*}{32} & M & $\begin{array}{c}44 \\
(28.4)\end{array}$ & $\begin{array}{c}12 \\
(7.7)\end{array}$ & $\begin{array}{c}87 \\
(56.1)\end{array}$ & & $\begin{array}{c}143 \\
(92.3)\end{array}$ \\
\hline & $\mathrm{L}$ & & & $\begin{array}{c}12 \\
(7.7)\end{array}$ & & $\begin{array}{c}12 \\
(7.7)\end{array}$ \\
\hline \multirow[t]{2}{*}{34} & M & & & $\begin{array}{c}43 \\
(100.0)\end{array}$ & & $\begin{array}{c}43 \\
(100.0)\end{array}$ \\
\hline & & 272 & 145 & 391 & 107 & \\
\hline
\end{tabular}

Values in parenthesis denotes the Percentage

In the case of Diamond shape, 272 prefer light shade, 145 prefer dark shade, 391 prefer neutral shades and 107 prefer bright shades. Out of 272, 74 of S and 15 of M belongs to 28; 139 of M belongs to 30" and 44 of M belongs to 32 ”. In the case of Dark shades, out of 145, 11 of XS belongs less than 28". 51 of XS and 60 of S belongs to 28 ". Wherein 11 of $\mathrm{M}$ in 30" and 12 of M in 32". Among 391, 31 of XS of Less than 28”. 124 of S belongs to 28 ", 20 of S and 74 of M belongs to 30". 87 of M in belong to 32" wherein 43 of M belongs to 34”. Out of 107 of bright shades, 12 of XS, 29 of S and 66 of M belong to 28 ".

\section{ROUNDED SHAPE}

The rounded shape respondents' colour preferences were shown in Table 13.

Table 13: Rounded Shape Vs Size Measurement Top and Bottom and Colour Preference

\begin{tabular}{|c|l|c|c|c|c|c|}
\hline $\begin{array}{c}\text { Bottom } \\
\text { Size }\end{array}$ & $\begin{array}{c}\text { Top } \\
\text { Size }\end{array}$ & $\begin{array}{c}\text { Light } \\
\text { Shades }\end{array}$ & $\begin{array}{c}\text { Dark } \\
\text { Shades }\end{array}$ & Neutral & $\begin{array}{c}\text { Bright } \\
\text { Shades }\end{array}$ & Total \\
\hline $\begin{array}{c}\text { Less } \\
\text { than 28 }\end{array}$ & XS & & & $\begin{array}{c}42 \\
(100.0)\end{array}$ & & $\begin{array}{c}42 \\
(100.0)\end{array}$ \\
\hline & XS & & $\begin{array}{c}51 \\
(11.8)\end{array}$ & $\begin{array}{c}12 \\
(2.8)\end{array}$ & & $\begin{array}{c}63 \\
(14.6)\end{array}$ \\
\cline { 2 - 7 } 28 & S & $\begin{array}{c}143 \\
(33.2)\end{array}$ & $\begin{array}{c}101 \\
(23.4)\end{array}$ & $\begin{array}{c}43 \\
(10.0)\end{array}$ & & $\begin{array}{c}287 \\
(66.6)\end{array}$ \\
\hline
\end{tabular}




\begin{tabular}{|c|l|c|c|c|c|c|}
\hline & M & & & $\begin{array}{c}81 \\
(18.8)\end{array}$ & & $\begin{array}{c}81 \\
(18.8)\end{array}$ \\
\hline \multirow{3}{*}{30} & S & & $\begin{array}{c}20 \\
(8.2)\end{array}$ & & & $\begin{array}{c}20 \\
(8.2)\end{array}$ \\
\cline { 2 - 7 } & $\mathrm{M}$ & 15 & 54 & 155 & & 224 \\
$(6.1)$ & $(22.1)$ & $(63.5)$ & & $(91.8)$ \\
\hline \multirow{3}{*}{32} & $\mathrm{M}$ & & $\begin{array}{c}56 \\
(36.1)\end{array}$ & $\begin{array}{c}87 \\
(56.1)\end{array}$ & & $\begin{array}{c}143 \\
(92.3)\end{array}$ \\
\cline { 2 - 7 } & $\mathrm{L}$ & & $\begin{array}{c}12 \\
(7.7)\end{array}$ & & & $\begin{array}{c}12 \\
(7.7)\end{array}$ \\
\hline \multirow{2}{*}{34} & $\mathrm{M}$ & 43 & & & & $\begin{array}{c}43 \\
(100.0)\end{array}$ \\
\hline \multicolumn{2}{|c|}{ Total } & $\mathbf{2 0 1}$ & $\mathbf{2 9 4}$ & $\mathbf{4 2 0}$ & & \\
\hline
\end{tabular}

Values in parenthesis denotes the Percentage

In the case of Rounded shape, 201 prefer light shade, 294 prefer dark shad and 420 prefer neutral shades. Bright shades have not been preferred by the respondents in any of the sizes. Out of 201 of light shades, 143 of S belong to 28 ", 15 of M belong to 30" and 43 of M belong to 34". Out of 294 of dark shades, 51of XS and 101 of S belongs to 28 ". 20 of size S and 54 of M belongs to 30”. 56 of M and 12 of L belongs to 32”.

Out of 420 of neutral shades, 42 of XS belong to less than 28". 12 of XS, 43 of S and 81 of M belongs 28 ". 155 of M belong to 30" and the remaining of the 87 of M belongs to 32 .

The shape, size and colour matrix have been derived and the same is shown in Table 14 .

Table 14: Shape, Size and Colour Matrix

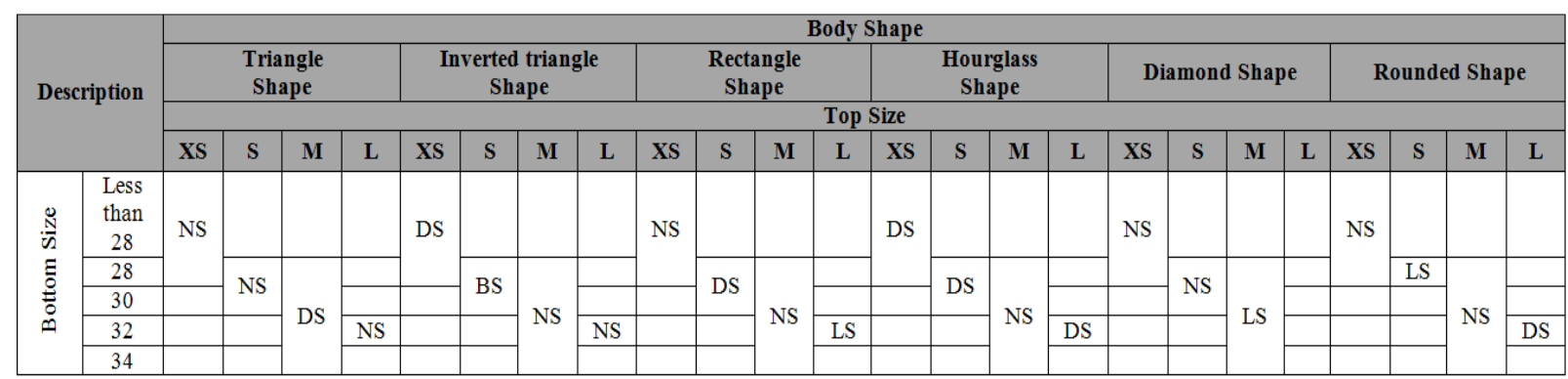

Table 15: Shape, Size and Colour Matrix

\begin{tabular}{|c|c|c|c|c|c|c|}
\hline Shapes & $\mathbf{X S}$ & $\mathbf{S}$ & $\mathbf{M}$ & $\mathbf{L}$ & $\mathbf{X L}$ & XXL \\
\hline Triangle Shape & $\begin{array}{l}>28-28 \\
\text { Neutral } \\
\text { Shades }\end{array}$ & $\begin{array}{c}28-30 \\
\text { Neutral } \\
\text { Shades }\end{array}$ & $\begin{array}{c}\text { 28-34 } \\
\text { Dark } \\
\text { Shades }\end{array}$ & $\begin{array}{c}32 \\
\text { Neutral } \\
\text { Shades }\end{array}$ & - & - \\
\hline Inverted Triangle Shape & $\begin{array}{c}>28-28 \\
\text { Dark } \\
\text { Shades }\end{array}$ & $\begin{array}{l}\text { 28-30 } \\
\text { Bright } \\
\text { Shades }\end{array}$ & $\begin{array}{c}28-34 \\
\text { Neutral } \\
\text { Shades }\end{array}$ & $\begin{array}{c}32 \\
\text { Neutral } \\
\text { Shades }\end{array}$ & - & - \\
\hline Rectangle Shape & $\begin{array}{l}>28-28 \\
\text { Neutral } \\
\text { Shades }\end{array}$ & $\begin{array}{c}\text { 28-30 } \\
\text { Dark } \\
\text { Shades }\end{array}$ & $\begin{array}{c}\text { 28-34 } \\
\text { Neutral } \\
\text { Shades }\end{array}$ & $\begin{array}{c}32 \\
\text { Light } \\
\text { Shades }\end{array}$ & - & - \\
\hline Hourglass Shape & $\begin{array}{c}>28-28 \\
\text { Dark } \\
\text { Shades }\end{array}$ & $\begin{array}{c}\text { 28-30 } \\
\text { Dark } \\
\text { Shades }\end{array}$ & $\begin{array}{c}28-34 \\
\text { Neutral } \\
\text { Shades }\end{array}$ & $\begin{array}{c}32 \\
\text { Dark } \\
\text { Shades }\end{array}$ & - & - \\
\hline Diamond Shape & $\begin{array}{l}>28-28 \\
\text { Neutral } \\
\text { Shades }\end{array}$ & $\begin{array}{c}28-30 \\
\text { Neutral } \\
\text { Shades }\end{array}$ & $\begin{array}{c}\text { 28-34 } \\
\text { Light } \\
\text { Shades }\end{array}$ & $\begin{array}{c}32 \\
\text { Neutral } \\
\text { Shades }\end{array}$ & - & - \\
\hline Rounded Shape & $\begin{array}{l}>28-28 \\
\text { Neutral } \\
\text { Shades }\end{array}$ & $\begin{array}{c}\text { 28-30 } \\
\text { Light } \\
\text { Shades }\end{array}$ & $\begin{array}{c}28-34 \\
\text { Neutral } \\
\text { Shades }\end{array}$ & $\begin{array}{c}32 \\
\text { Dark } \\
\text { Shades }\end{array}$ & - & - \\
\hline
\end{tabular}


The inferences drawn from Table 14 and 15 are as follows:

- The neutral shades are the most preferred shades by Less than 28 and 28 in XS preferred by Triangle, Rectangle, Diamond and Rounded shapes.

- The neutral shades are the most preferred shades 28, 30, 32 and 34 of M preferred by Inverted Triangle, Rectangle, Hourglass and Rounded shapes whereas the Light shade preferred by Diamond shape.

- The neutral shade of 32 only preferred by L in Triangle and Inverted triangle shapes whereas Light shade is preferred by L in Rectangle and Dark shade in Hourglass and Rounded shapes.

- The dark shades are the most preferred shades by Less than 28 and 28 in XS preferred by Inverted triangle and Hourglass shapes.

- $\quad$ The dark shades of $\mathrm{M}$ in 28, 30, 32 and 34 preferred by Triangle shape.

- 28 and 30" of S in Inverted triangle shape preferred bright shade.

- $\quad$ There is no shade preference for XL and XXL.

\section{CONCLUSIONS}

The study was carried out with the objective to identify the different shapes of unisex clothing, to identify the different sizes of Unisex clothing, to identify the colour and shade preferred for unisex clothing and to frame a shape, size and colour for different body shape towards manufacturing unisex clothing.

Six different body shapes such as Triangle shape, Inverted triangle shape, Rectangle shape, Hourglass shape, Diamond shape and Rounded shapes were considered for the study. The size measurements have been normally of two types such as bottom size and top size. For unisex clothing, the bottom has been indicated as Less than 28”, 28”, 30", 32" and 34". The most preferred top size for unisex clothing were XS, S, M and L. The study also identifies the colour preferences for unisex clothing.

The neutral shades are the most preferred shades by Less than 28 and 28 in XS preferred by Triangle, Rectangle, Diamond and Rounded shapes. The neutral shades are the most preferred shades 28, 30, 32 and 34 by $\mathrm{M}$ preferred by Inverted Triangle, Rectangle, Hourglass and Rounded shapes whereas the Light shade preferred by Diamond shape. The neutral shade of 32 only preferred by L in Triangle and Inverted triangle shapes whereas Light shade is preferred by $\mathrm{L}$ in Rectangle and Dark shade in Hourglass and Rounded shapes. The dark shades are the most preferred shades by Less than 28 and 28 in XS preferred by Inverted triangle and Hourglass shapes.

The results are interesting and will give important insights to the marketer to redefine the strategies of retailing fashion apparel in India considering the global-local influences. It was found in the study that there is a complete awareness of the unisex apparels amongst male and female. The culture is shifting towards unisex apparel. It is observed that Size, Fit and Colour are significant factors in unisex apparels. 


\section{REFERENCES}

1. Adams, G., Turner, H., \& Bucks, R. (2005). The experience of body dissatisfaction in men. Body Image, 2,271-283.

2. Alexander, M., Connell, L. J., \& Presley, A. B. (2005). Clothing fit preferences of young female adult consumers In; International Journal of Clothing Science and Technology, 17, 52-64.

3. Ashdown, S. P., \& Dunne, L. (2006). A study of automated custom fit: Readiness of the technology for the apparel industry. Clothing and Textiles Research Journal, 24, 121-136.

4. Bergeron, D., \& Tylka, T. L. (2007). Support for the uniqueness of body dissatisfaction from drive for muscularity among men. Body Image, 4, 288-295.

5. Bickle, M. C., Kotsiopulos, A., Dallas, M. J., \& Eckman, M. (1995). Fit of women's jeans: An exploratory study using disconfirmation paradigm. Journal of Consumer Satisfaction, Dissatisfaction and Complaining Behavior,8, $208-213$.

6. Butler, J. (1993). Bodies that Matter: On the Discursive Limits of „Sex“. New York:

7. Cafi, G., \& Thompson, J. K. (2004). Measuring male body image: A review of the current methodology. Psychology of Men \& Masculinity, 5, 18-29.

8. Chattaraman, V., \& Rudd, N. A. (2006). Preferences for aesthetic attributes in clothing as a function of body image, body cathexis and body size. Clothing and Textiles Research Journal, 24, 46-61.

9. Couch J. (Eds.), Communication and social structure. Springfield: Charles \& Thomas.

10. Davis, F. (1985). Clothing and Fashion as Communication. In Solomon, M. (Ed.). The psychology of fashion. Lexington: Lexington Books.

11. DesMarteau, K. (2000, October). Let the fit revolution begin. Bobbin publishing group. just-style.com. Retrieved from http://www.just-style.com/analysis/let-the-fit-revolution-begin_id92196.aspx

12. Khurana, K. Sustainable Supply Chain Management in Fashion \& Textile Companies-A Study on Existing Sustainable Tools and Models.

13. Feather, B. L., Ford, S., \& Herr, D. G. (1996).Female collegiate basketball players' perceptions about their bodies, garment fit and uniform design preferences. Clothing and Textiles Research Journal,14, 22-29.

14. Frith, H., \& Gleeson, K. (2004). Clothing and embodiment: Men managing body image and appearance. Psychology of Men and Masculinity, 5, 40-48.

15. Giovis, J. (2007, January 22). More fitting clothes urged: Women discouraged by inconsistent sizes. Chicago Tribune: Business. Retrieved from <http://articles.chicagotribune.com/2007-01-22/business/0701220053_1_fit-technologies-apparelindustry-long-torso>

16. Hobson, K. (2002). Chic-and comfortable: Chico's prospers selling clothes for real women. US News \&World Report, 132, 40.

17. Howarton, R., \& Lee, B. (2010). Market analysis of fit preferences of female boomers. Journal of Fashion Marketing and Management, 14, 219-229.

18. Manuel, H. M., Connell, L. J., \& Presley, A. B. (2010). Body shape and fit preference in body cathexis and clothing benefits sought for professional African-American women. International Journal of Fashion Design, Technology and Education, 3, 2532. 
19. Newcomb, E., \& Istook, C. L. (2011). Confronting stereotypes: Apparel fit preferences of Mexican-American women. Journal of Fashion Marketing and Management, 15, 389-411.

20. Pisut, G., \& Connell, L. J. (2007). Fit preferences of female consumers in the USA. Journal of Fashion Marketing and Management, 11, 366-379.

21. Karunaratne, P. V. M. Mundane beauty: Female fashion of costumes addressing drapes and folds as fashion devices used in female costumes during 16th century in Sri Lanka.

22. Ridgeway, R. T., \& Tylka, T. L. (2005).College men's perceptions of ideal body composition and shape. Journal of Men and Masculinity, 6, 209-220.

23. Sawyer, C. (1987). Men in Skirts and Women in Trousers, from Achilles to Victoria Grant: One Explanation of a Comedic Paradox. The Journal of Popular Culture, 21, $1-18$.

24. Shim, S., \&Bickle, M. C. (1993). Women 55 years and older as catalog shoppers: Satisfaction with apparel fit and catalog attributes. Clothing and Textiles Research Journal, 11, 53-64.

25. Simmons, K. P., \& Istook, C. L. (2003). Body measurement techniques: A comparison of three-dimensional body scanning and physical anthropometric methods for apparel application. Journal of Fashion Marketing and Management, 7, 306-332.

26. Stanforth, N. (2009) Fashion merchandising internships for the millennial generation. International Journal of Fashion Design, Technology and Education 2 (2-3): 91-99.

27. Sunitha Vasan, Pujar, SR \& Gopalakrishnan.S. (2017). Awareness on Unisex Clothing Among Fashion Designers: A Study. International Journal in Management and Social Sciences, 5(2), 14-23.

28. Sunitha Vasan, Pujar, S R \& Gopalakrishnan.S. (2017). Perception on Unisex Clothing Among Apparel Designers: A Study. International Journal of Textile and Fashion Technology (IJTFT), 7(2), 17-26.

29. Manokari, S. L., \& Kirthiga, E. Salwar Kameez Designing for College Going Girls.

30. Tager, T., Good, G. E., \& Morrison, J. B. (2006). Our bodies, ourselves revisited: Male body image and psychological wellbeing. International Journal of Men's Health, 5, 228-238.

31. Tiggeman, M., \& Pennington, B. (1996). The development of gender differences in body-size dissatisfaction. Australian Psychologist, 25, 306-313.

32. Yoo, S. (2003). Design elements and consumer characteristics relating to design preferences of working females. Clothing and Textiles Research Journal, 21, 49-62. 
